\title{
Toxocariasis: visceral larva migrans in children
}

\author{
Elaine A. A. Carvalho, ${ }^{1}$ Regina L. Rocha²
}

\begin{abstract}
Objectives: To present a detailed investigation of risk factors, symptoms, and laboratory and imaging tests that may be useful to establish the clinical laboratory diagnosis of visceral larva migrans (VLM) in children, demonstrating the importance of diagnosis and treatment to prevent complications in the eyes, liver, and other organs.

Sources: Literature review using the MEDLINE and LILACS (1952-2009) databases, selecting the most recent and representative articles on the topic.

Summary of the findings: VLM is an infectious disease with non-specific clinical presentation, whose transmission is related to contact with dogs, especially puppies, and which may progress to late systemic complications in vital organs such as the eyes and the central nervous system. IgG (ELISA) anti-T. canis can be used to establish the laboratory diagnosis. Higher cutoff points suggest recent illness and lower cutoff points demonstrate mild infection or infection in remission. Therapeutic response may be assessed by means of eosinophil blood cell count. The present article provides the pediatrician with updated information regarding VLM, a disease of high prevalence worldwide and in Brazil.

Conclusions: The diagnosis of VLM depends mainly on the presence of dogs in the child's household, associated with ELISA (IgG anti-T. canis), using excretory-secretory antigens of Toxocara canis. Prospective studies are warranted to assess the best drug therapy. Prevention is the most important strategy because of the high prevalence of $T$. canis in urban areas.
\end{abstract}

J Pediatr (Rio J). 2011;87(2):100-110: Toxocara canis, dogs, infection, epidemiology, ELISA, prevalence.

\section{Introduction}

The term visceral larva migrans (VLM) syndrome was first used by Beaver et al. ${ }^{1}$ in 1952, when the authors reported on the clinical picture of three children with significant chronic eosinophilia, hepatomegaly, lung infiltration, fever, cough, and hyperglobulinemia caused by penetration of nematode larvae in the liver and possibility of migration to other organs. Beaver et al. ${ }^{1}$ used the term VLM to describe the migration of larvae at second stage through the organs of a human host, ${ }^{1}$ finding and identifying the second stage of the larva Toxocara canis, the common dog ascarid, in children's tissues. ${ }^{2}$

$T$. canis and $T$. cati are found throughout the world because of human settlement in nearly all regions of the
Earth. The tendency of human beings (almost a genetic obligation) to live with several pets, particularly cats and dogs, has promoted the worldwide distribution of toxocariasis. ${ }^{3}$

The high prevalence of this disease in children all around the world and in Brazil has prompted this literature review. The difficulty to establish the diagnosis of this infection because of the diversity of symptoms and possible complications in the eyes, brain, liver, and other organs suggested the need for wide dissemination of information on this topic. We used the MEDLINE and LILACS databases, selecting the latest and most representative article and textbooks on this topic, covering the period from 1952 to 2009.

1 Doutora, Ciências da Saúde, Infectologia e Medicina Tropical, Universidade Federal de Minas Gerais (UFMG), Belo Horizonte, MG, Brazil. Professora adjunta, Departamento de Pediatria, UFMG, Belo Horizonte, MG, Brazil. Membro, Grupo de Infectologia Pediátrica, UFMG, Belo Horizonte, MG, Brazil.

2. Doutora, Ciências da Saúde, Infectologia e Medicina Tropical, UFMG, Belo Horizonte, MG, Brazil. Professora adjunta, Departamento de Pediatria, UFMG, Belo Horizonte, MG, Brazil.

No conflicts of interest declared concerning the publication of this article.

Suggested citation: Carvalho EA, Rocha RL. Toxocariasis: visceral larva migrans in children. J Pediatr (Rio J). 2011;87(2):100-110. 


\section{Epidemiology}

The genus Toxocara belongs to the phylum Nemathelminthes, class Nematoda, order Ascaroidea, family and subfamily Ascarinae and comprises 21 species. The species $T$. canis (Belascaris marginata), T. cati (Toxocara mystax), and Toxascaris leonina are the most commonly involved in the VLM syndrome. ${ }^{4}$ The ascarids responsible for causing toxocariasis in the human host are $T$. canis and $T$. cati. ${ }^{3}$

Adult worms live on average 4 months and, after about 6 months, almost all are spontaneously eliminated by the host. ${ }^{4}$ The female $T$. canis produces up to 200,000 eggs, ${ }^{5}$ which are resistant to hostile factors and may remain viable for long periods in soil. ${ }^{4}$ The eggs are not embryonated in faeces and therefore are not infectious. Appropriate conditions of temperature ( 15 to $35^{\circ} \mathrm{C}$ ) and humidity are necessary to ensure embryonation, and under these conditions, $85 \%$ of the eggs become infectious within 2 to 5 weeks. ${ }^{6}$

The definitive host is the domestic dog, in which the parasite lives as an adult inside the lumen of the small intestine. ${ }^{3}$ The history of $T$. canis depends on the age and sex of the dog. ${ }^{5}$ After embryonation under appropriate environmental conditions, dogs can become infected in several different ways.

a) Ingestion of infective eggs: the dog ingests the embryonated egg, which appears in the faeces 4-5 weeks after infection. ${ }^{4,5}$

b) Ingestion of larva and tissues of paratenic hosts (earthworms, ants and other invertebrates that inhabit the soil). ${ }^{3}$

c) Transplacental migration: prevalence of $T$. canis in pups is about $100 \%$. $^{7}$

d) ransmission of the larva from the milk of a female dog that nurses her pups: the presence of larvae in the colostrum reaches its maximum rate during the 2 nd week of lactation. 4

e) Female dog ingestion of the larvae of $T$. canis found in the vomit or feces of pups while cleaning them. ${ }^{4}$

Dog defecation in public places contributes to environmental contamination with Toxocara, promoting zoonotic transmission. 5 Studies in Brazil have found parasite eggs in the soil8; contamination ranged from 17.5 to $53.3 \% .^{9-14}$

Child infection occurs by ingestion of eggs of $T$. canis ${ }^{15}$ by means of direct contamination of the hands and, especially, the fingers; direct contact with pups, mainly those aged between 2 weeks and 6 months; indirectly, by means of contact with objects contaminated with infected eggs inside or outside the home, and by ingestion of soil containing larvae or infected eggs.

VLM syndrome is a disease caused by ingestion of soil ${ }^{16-18}$ containing larvae or eggs infected with $T$. canis. ${ }^{19}$ Geophagy was not statistically significant for some authors. 16,19-21
Some studies have reported the presence of pica (eating inedible substances) in children with VLM1,3,22-28; whereas others have reported an association between pica and toxocariasis. ${ }^{5,29-32}$ Pica is detected in many children with VLM, with a higher prevalence among children between 1 and 6 years ( 10 to $30 \%$ ) and being slightly more common in boys than in girls. ${ }^{19} \mathrm{Glickman}$ et al. ${ }^{19}$ showed an association between specific forms of pica for feces, dirt or ashes and infection with $T$. canis in 100 children between 1 and 6 years. A 2005 study showed an association between positive serology for $T$. canis and the presence of pups and contact with dirt among children with a mean age of 6.5 years. ${ }^{16} \mathrm{~A}$ study has shown no association of nail biting with positive serology for $T$. canis ${ }^{16}$; however, in another study, nail biting was a risk factor for toxocariasis. 33

The presence of a dog in the house was a risk factor for seropositivity in several studies. $17,19,20,23,24,30,31,34-36$ Some authors have found no association between dog owners ${ }^{17}$ and frequency of Toxocara infection, which could be explained by appropriate hygiene measures taken by adults. Other studies have shown an association between positive serology for $T$. canis in owners of pups under 3 months. ${ }^{16,30}$

Iddawela et al. showed that the socioeconomic status was not significant as a risk factor for toxocariasis. ${ }^{30}$ Other authors have shown a significant association between seropositivity and socioeconomic indicators, such as low income and education level.5,33,37 Several authors have found a high prevalence in regions with low purchasing power, low rate of urbanization, and where part of the population did not have access to sanitary conditions. ${ }^{17,33,38}$ The highest rates of seroprevalence are associated with low socioeconomic and/or educational level.19,21,39-43 In Brasilia, the federal capital of Brazil, a study has demonstrated seropositive for $T$. canis of $21.8 \%$ in samples collected in the laboratory of a public hospital and $3 \%$ in middle-class children attending a private laboratory. ${ }^{44}$ Some studies have shown an association between living in a rural area and toxocariasis. 17,20,35,45

The prevalence of antibodies of $T$. canis in the healthy population shows great territorial variability. ${ }^{5}$

Several studies have shown seroprevalence ranging between 9.7 and 43\%. ${ }^{30,37,46-49}$ Other studies describing isolated cases have shown toxocariasis in children between 16 months and 6 years. ${ }^{1,50-54}$ Other studies conducted in Brazil, with larger sample size, have shown prevalence between 1 and 14 years. $13,16,31,33,55 \mathrm{~A}$ similar finding was detected in studies conducted in other countries. ${ }^{30,56}$ Glickman found the average age of 5.6 years in 1980 (unpublished results). In developed countries, the prevalence was higher in children up to 7 years; $5,32,57$ but a study conducted in the state of Rio Grande do Sul has shown toxocariasis in children from 8 months to 7 years of age. ${ }^{26}$ In other Brazilian studies, the prevalent age was over 5 years. ${ }^{13,31,33,55}$ Case-control studies did not find a significant difference in terms of age. $17,29,33,35-37,58$ 
Several authors have shown a higher prevalence in males, $19,37,39,41,42,46$ with a male ratio of $1.5: 1$ and a female ratio of $2 \cdot 3: 1.5,26,28,58$ Similarly to what happens with adults, this relationship is up to three times higher in males compared to females in children. ${ }^{59}$ However, in several studies, there was no statistical difference between male and female patients with toxocariasis. ${ }^{16,20,29-33,35,36,44,55}$

In Brazil, seroepidemiological studies on human toxocariasis have shown variation in the prevalence from 7 to $54.8 \% .13,16,33,42,55,60-66$

\section{Pathogenesis}

Several factors may contribute to the pathogenesis of toxocariasis in human beings 2,5 : inflammatory reactions triggered by the presence of larvae in the tissue; host's immune conditions; frequency of intake of egg larvae; number of larvae ingested; host sensitization to antigens typical of the larva; and host sensitization to products secreted and/or excreted by the larva.

Experimental studies in animals with larval T. canis and observations of its behavior, distribution, persistence, and pathogenicity in humans show that the type of infection caused by this species is markedly different from those produced by nematodes: the inactive larva of Toxocara may be reactivated at some point and migrate again. ${ }^{67}$

The pathogenic mechanisms of VLM and ocular larva migrans (OLM) are different. ${ }^{5}$ Smaller amounts of Toxocara larvae are associated with increased probability of OLM than VLM, ${ }^{5}$ which may explain why antibody titers of Toxocara are generally lower in cases of OLM than in cases of VLM. ${ }^{4}$

In biopsies and autopsies of naturally infected children and experimentally infected animals, tissue invasion by larvae results in an encapsulation of the $T$. canis larva in the host tissue, which can be considered a reaction that promotes long stay and prolonged infectivity of the larvae. ${ }^{2}$

\section{Clinical manifestations}

Many infections caused by Toxocara are asymptomatic and may reach $44.4 \%$ of prevalence, 58 and systemic toxocariasis occurs in around $15.5 \%$ of the diagnosed cases. ${ }^{68}$

Because of the variability of signs and symptoms of the disease, in 1988 toxocariasis was divided into two main forms: VLM and ocular toxocariasis. ${ }^{69}$ Between 1992 and 1993, a third clinical form called covert toxocariasis was described in seropositive patients, with gastrointestinal disturbances, weakness, and lethargy. ${ }^{70,71}$

The proposed new classification was the association between the state of clinical observation, the involvement of immunopathogenic mechanisms, including the degree of serological response, and the location of the Toxocara larva. This classification divides human toxocariasis into: classical systemic, asymptomatic, covert, and compartmentalized (ocular and neurological). The last two forms should be classified separately, as probably the eyes or the brain are the final sites of migration for the Toxocara larva. ${ }^{67}$ These classification and approach to clinical therapy (based on clinical and laboratory abnormalities) and preventive treatment (to avoid possible complications in the eyes and brain) are shown in Table 1.72

\section{Classical systemic visceral larva migrans}

VLM syndrome was described by Beaver et al., ${ }^{1}$ in 1952, as a severe systemic form, characterized by high eosinophilia, hepatosplenomegaly, fever, hypergammaglobulinemia, ${ }^{1}$ high isohemagglutinin titers, leukocytosis, ${ }^{73}$ occurring in children between 1 and 5 years of age, for an average of 2 years. ${ }^{73}$ Among the possible consequences of prolonged and severe eosinophilia are pulmonary fibrosis and eosinophilic myocardial fibrosis. ${ }^{74-76}$

Snyder ${ }^{25}$ reported on 20 children between 16 and 48 months, with VLM; history of geophagy and fever (55\%);

Table 1 - Classification of clinical forms of human toxocariasis and rationale for clinical and preventive treatments

\begin{tabular}{|c|c|c|c|c|c|c|c|}
\hline \multirow[b]{2}{*}{ Clinical forms } & \multicolumn{5}{|c|}{ Patient's clinical characteristics (intensity) } & \multicolumn{2}{|c|}{ Rationale of treatment } \\
\hline & Symptoms & Signs & Serology & Eosinophilia & IgE & Clinical* & Preventive* \\
\hline \multicolumn{8}{|l|}{ VLM } \\
\hline Classical & High & Moderate & High & High & Moderate & Yes $^{+}$ & \\
\hline Incomplete & Mild & Mild & Moderate & Moderate & Mild & Yes & Yes $^{\ddagger}$ \\
\hline OLM & High & High & Mild & Uncertain & Uncertain & Yes & \\
\hline NLM & Mild & Mild & Mild & Uncertain & Uncertain & Yes & \\
\hline Covert toxocariasis & Uncertain & Mild & Moderate & Uncertain & Moderate & Yes & Yes $^{\ddagger}$ \\
\hline Asymptomatic toxocariasis & None & None & Mild & Uncertain & Uncertain & No & $\begin{array}{c}\text { To be } \\
\text { considered }\end{array}$ \\
\hline
\end{tabular}

$\operatorname{lgE}=$ immunoglobulin $\mathrm{E} ; \mathrm{NLM}=$ neurological larva migrans; OLM = ocular larva migrans; VLM = visceral larva migrans.

* A course of albendazole $15 \mathrm{mg} / \mathrm{kg} /$ day for 5 days.

$\dagger$ In some cases treatment must be repeated.

‡ If positive serology and eosinophilia $>400 / \mathrm{mm}^{3}$. 
pallor (40\%); coughing or bronchospasm (20\%); moderate hepatomegaly (85\%); and mild splenomegaly (45\%). All patients had marked leukocytosis, eosinophilia above $50 \%$ in $60 \%$ of cases, reaching $90 \%$ in one case. ${ }^{25}$

Baldisserotto et al. ${ }^{77}$ described 18 cases of toxocariasis showing the following clinical findings: hepatomegaly $(72.7 \%)$, splenomegaly (50\%), history of contact with pups $(38.8 \%)$, cervical adenitis $(33.3 \%)$, pulmonary symptoms (27.7\%), fever (22.2\%), pallor (16.6\%), geophagy (16.6\%), limb pain $(11.1 \%)$, and skin lesions $(5.5 \%)$, and $16.6 \%$ were asymptomatic.

Gónzalez et al.50 described VLM characterized by fever, leukocytosis with persistent eosinophilia, hypergammaglobulinemia, and hepatomegaly. In some cases, there was wheezing, and $1 / 3$ of patients had pulmonary infiltrates. 50

Altcheh et al. ${ }^{58}$ found fever in $5.5 \%$ of patients. These findings are in disagreement with other studies in which symptomatic patients had higher prevalence fever. ${ }^{25}$ Iddawela et al. ${ }^{30}$ showed an association between fever and positive ELISA for $T$. canis.

Some authors who conducted case-control studies found no significant difference between anthropometric measures and positive serology for $T$. canis. ${ }^{24}$ Figueiredo et al. ${ }^{16}$ found an association between lower height for age and seropositivity for $T$. canis.

Some studies have shown that anemia (assessed by means of hemoglobin) was not significant regarding the presence of $T$. canis. $16,17,58$ On the other hand, there are reports of isolated cases of children with anemia and toxocariasis. 1,25,47,50,52,78,79 There are several isolated reports of leukocytosis in patients with toxocariasis. 1,25,26,51-53,55,76-81 Glickman et al. ${ }^{32}$ showed an association between increased white blood cell count above 10,000 cells $/ \mathrm{mm}^{3}$ and positive ELISA for $T$. canis.

Weight loss was associated with positive serology for $T$. canis by Iddawela et al. 30

Incomplete VLM, which was proposed by Luzna-Lyskov et al. ${ }^{76}$ in 2000 , is restricted to cases clinically much less severe in which only a few signs of the VLM form may occur, such as increased hepatomegaly and eosinophilia in patients with positive serology (ELISA) anti-Toxocara. ${ }^{76}$

\section{Neurological and ocular larva migrans}

Ocular toxocariasis occurs primarily in young patients and affects men and women with similar frequency. In the literature, the prevalence ranged from 0 to $10 \%, 31,58,82$ and the age ranged from 3 to 11 years 22,69 with a mean of 8 years. ${ }^{73}$ In an isolated case report, age was 9 years. ${ }^{27}$ Glickman, in 1980, conducted a study involving 90 patients with VLM and found OLM in 34 patients with mean age of 12.1 years, male:female ratio of $2.4: 1$, and duration of 2 years when there was association of OLM and VLM. ${ }^{5}$
The disease is unilateral in most cases, with mild to moderate or diffuse inflammation. ${ }^{83,84}$ Clinical presentation ranges from granuloma in the peripheral retina in $50 \%$ of eyes, $25 \%$ in the macula, and $25 \%$ have endophthalmitis. A granuloma may also occur in the optic nerve. The most common clinical signs and the major cause of vision loss are vitreous inflammation, cystoid macular edema, and traction of vitreoretinal filaments toward the optic nerve and/or granuloma. 85

Eosinophilia is usually absent in ocular toxocariasis, as reported by Magnaval et al. ${ }^{86}$ and Sabrosa \& de Souza 26 both in 2001 . Oréfice et al. ${ }^{83}$ reviewed 30 cases of possible OLM. Only 17 underwent ELISA, 15 cases were positive and all of them had unilateral vitritis. There were multiple and disseminated ocular lesions in the posterior pole inside the medial retina. ${ }^{83}$ Schantz et al. ${ }^{34}$ described ocular involvement 10 years after the diagnosis of VLM.

In Slovenia, 239 sera from patients with positive IgG ELISA T. canis test and confirmed by IgG Western-blot analysis showed unilateral ocular inflammatory manifestations such as peripheral or posterior retinochoroiditis, vitritis, papillitis or circumscribed endophthalmitis. ${ }^{87}$

In a case-control study with epileptic patients, the authors found associations between partial epilepsy and positive serology (ELISA) for $T$. canis. ${ }^{88}$ In 2004, a case of an 11-yearold child with generalized epileptic seizures, cystic hypodense lesion in the right parietal region, normal cerebrospinal fluid and positive serum ELISA for $T$. canis. ${ }^{89}$

\section{Covert toxocariasis}

Prior to the first report of VLM by Beaver et al.., ${ }^{1}$ there were reports on cases of eosinophilia associated with other clinical changes that could have been covert toxocariasis.

According to its definition, covert toxocariasis is characterized by nonspecific symptoms and signs, which are not associated with the categories of classical larva migrans, incomplete larva migrans, OLM, or NLM. The clinical manifestation of covert toxocariasis varies widely, with pulmonary involvement, such as asthma, acute bronchitis, pneumonia with or without Loeffler's syndrome, 90,91 skin problems, such as chronic urticaria or eczema, 92 lymphadenopathy, myositis, and pseudorheumatoid syndrome. ${ }^{93}$ Covert toxocariasis is often confirmed by the disappearance or alleviation of symptoms and signs after treatment with anti-Toxocara. ${ }^{67}$

\section{Asymptomatic toxocariasis}

Asymptomatic toxocariasis, diagnosed based on serology, occurs mainly in mild or old infections and may be accompanied by eosinophilia. ${ }^{94}$ Glickman et al. ${ }^{5}$ published a study of asymptomatic infection with a prevalence of $5 \%$ in White children (preschool and school age children) and almost $25 \%$ in Black children. ${ }^{5}$ 
A major concern regarding Toxocara seropositive asymptomatic children is the risk of progression from asymptomatic infection to NLM or OLM. ${ }^{94}$

In many populations, the occurrence of low but variable positive ELISA titers apparently suggests the prevalence of asymptomatic toxocariasis, ${ }^{73}$ which ranged in the literature between 7 and $44.4 \% .26,58,60,94$

\section{Visceral involvement of other systems}

Based on the description by Beaver et al., ${ }^{1}$ in 1952, there were several reports of toxocariasis with skin problems, but the diagnosis was not confirmed by biopsy. Atopic dermatitis was not associated with toxocariasis in published studies. ${ }^{16,95}$

Herry et al. ${ }^{81}$ described a case of cardiac tamponade in a 50-year-old man who were seropositive for $T$. canis.

In 1952, Beaver et al. ${ }^{1}$ described three children who had hepatomegaly, and one of them also had splenomegaly. They underwent laparotomy and biopsy (in only two of them the material was conclusive), showing an extensive area of hepatic necrosis and inflammation between the center of the necrosis and the portal space. The authors found the presence of eosinophilic leukocytes and epithelial and giant cells around the areas of necrosis. The larva of the parasite was found in the region of eosinophils without necrosis or other injuries, suggesting that the parasite had recently installed in the liver. ${ }^{1}$

There was no association between hepatomegaly and splenomegaly and positive serology for $T$. canis according to some authors in terms of hepatomegaly 32 and splenomegaly. ${ }^{16}$ Other authors have shown an association between toxocariasis and hepatomegaly. ${ }^{16,95}$ In several isolated cases of toxocariasis, hepatosplenomegaly has been reported. ${ }^{1}$ Other authors disagree on those findings, showing a prevalence of hepatomegaly ranging from 11.1 and $85 \%, 25,28,58$ and splenomegaly between 20 and $45 \%$. In a Brazilian study with larger sample sizes, hepatomegaly was found in $53.8 \%$ of children and splenomegaly in $3.8 \%{ }^{31}$ The liver may be slightly increased, as it was shown in $90.5 \%$ of 21 children with toxocariasis. ${ }^{96}$

Association between abdominal pain and seropositivity for toxocariasis has not been found in some studies. 16,97 Taylor et al. ${ }^{69}$ reported abdominal pain as one of the most common symptoms, especially in children with higher titers. Iddawela et al. ${ }^{30}$ hypothesized that the major cause of abdominal pain is idiopathic toxocariasis. Abdominal pain may caused by lymphadenitis as a host response to larval migration. 30

Since 1992, isolated cases of liver involvement with positive serologic test for $T$. canis in adults have been reported. ${ }^{78,98,99}$ However, until 1994, there have been cases of liver alterations on ultrasound in children with positive ELISA for anti-Toxocara antibody reported in the literature. ${ }^{79,100}$ Souza ${ }^{31}$ described 104 children with positive ELISA for $T$. canis, and $53.8 \%$ had hepatomegaly. Among these, $16.1 \%$ showed liver ultrasound images of hypoechogenic micronodular type, suggesting that they are compatible with eosinophilic granulomas. ${ }^{31}$

Baldisserotto et al. ${ }^{77}$ described 18 children with positive serology (ELISA) for toxocariasis. In 15 of them, the authors found ill-defined hypoechoic liver nodules whose diameters were up to $8 \mathrm{~mm}$. In 14 patients, there was hepatic hilar lymph node enlargement (77.7\%). Pancreatic lymph nodes were found in two children. The ultrasound revealed hepatomegaly and splenomegaly in 13 patients with homogeneous parenchyma in nine of them. Liver biopsy was performed in two children, which revealed eosinophilic exudation, but there were no larvae or granulomas. ${ }^{77}$ Gónzalez et al. ${ }^{50}$ described 16 children with positive serology (ELISA) for toxocariasis and ultrasound changes in the liver in $50 \%$ of them.

Since 2001, studies in adults with hepatic eosinophilic granulomas showing positive serology for Toxocara sp. ${ }^{101}$ and multiple hepatic lesions 59,102 have been published, as well as a report on three cases of children with liver granuloma on abdominal ultrasound. 58

There are reports in the literature on the association of liver abscess and toxocariasis, with the incidence ranging from 27 to $63 \%$. $^{103-105}$

Between 1996 and 2002, three confirmed cases of eosinophilic pleural effusion with positive ELISA for $T$. canis were described. ${ }^{106-108}$

The presence of asthma in patients with toxocariasis has been reported by some authors, 95 and the association between asthma and toxocariasis was described in some studies. ${ }^{16,109}$ Buijs et al. ${ }^{110}$ suggested that only children with atopic predisposition shown an association between infection with $T$. canis and allergic reactions; in agreement with that, Taylor et al. ${ }^{69}$ found no association between asthma and positive ELISA for $T$. canis.

The literature includes reports on the presence of bronchospasm in children with toxocariasis. ${ }^{25,31,51,73}$ Alderete et al. ${ }^{33}$ showed that wheezing was associated with positive serology. Other authors reported that respiratory symptoms, such as cough, were common among children with positive serology for $T$. canis, 30,95,111,112 however, a study conducted in Brazil found no association between seropositivity and cough. ${ }^{16}$ The reaction and the natural history of the host regarding the migration of the larva in the second stage inside the lungs have not been established. ${ }^{112}$

Lymphedema and high titers of ELISA for $T$. canis have been described. 52 We could not find studies showing an association between enlarged lymph nodes and positive ELISA for $T$. canis. Some authors have found an increase in peripheral lymph nodes in $0.96 \%$ of patients with toxocariasis. ${ }^{51}$ 
Other systems are also affected by toxocariasis and this has been described by some authors: arthritis in both knees and high titers of ELISA, 113 tropical pyomyositis associated with toxocariasis, ${ }^{114,115}$ thrombocytosis in two children. ${ }^{54}$

\section{Immune response}

In 1952, Beaver et al. ${ }^{1}$ reported that the immune response to helminthiasis is caused by larval migration stages in tissues and occurs in conjunction with this migration.

The host's immune response may include both humoral and tissue factors. Unspecific tissue reactions may occur after the first contact between the host and the parasite and specific reactions (granuloma) may occur after reexposure. ${ }^{6}$ During the initial stage of infection, first there is acute inflammation characterized by aggregates of eosinophils, neutrophils, and some monocytes, and the larvae are partially surrounded by a capsule of collagen. On the other hand, in chronic infections, the larvae are usually encapsulated by mature granulomas with its central portion formed by mononuclear cells or leukocytes. The presence of larvae is not essential for the formation of mature granuloma. The release of Toxocara excretory-secretory antigens (TES) is responsible for initiating the inflammatory response. That is the reason why the larvae are not found in many granulomas and, when found, they are intact and presumably viable. ${ }^{45}$

The pathological consequences depend on the death of the larvae of $T$. canis. Their death triggers the beginning of early and delayed hypersensitivity responses. ${ }^{3}$ The formation of granulomas is considered a manifestation of delayed hypersensitivity $\left(\mathrm{Th}_{1}\right)$, whereas $\mathrm{IgE}$ and eosinophilia are typical of $\mathrm{Th}_{2}$-mediated responses. ${ }^{39}$

The reason for the development of the symptomatic form of VLM is not completely clear, but the incriminating factors are some types of immune response. The major host responses to the antigens include marked eosinophilia and hypergammaglobulinemia. IgE antibodies and eosinophils are manifestations of $\mathrm{Th}_{2}$ of Thelper cells and of the cytokines secreted by these cells (especially IL- 1 and interferon- $\gamma$ ). And there is reason to believe that the antigens released from the $T$. canis larva prompt the induction of this population of cells. There is much evidence that the chronic production of parasite antigens, continuous stimulation of host immune system, and concomitant production of eosinophils can cause systemic complications. The liver is one of the most common sites for these lesions and hepatic involvement because of portal drainage of organs. ${ }^{39,116}$

\section{Diagnosis}

In 1996, Carme117 described that because of polymorphism and absence of specific signs of the disease, it is necessary to use complementary tests to establish the diagnosis. Diagnosis of VLM involves clinical, laboratory, ultrasonographic, anatomical/pathological and immunodiagnostic factors.

The eosinophilia measured in peripheral blood is proportional to the tissue eosinophilia, where there is local reaction to the Toxocara larva or the antigens remain in the tissue following the larval migration. ${ }^{118}$ The occurrence of eosinophilia in Toxocara seropositive cases evidences both the activity of the infection and the antibody response. ${ }^{76}$ Pawlowski ${ }^{67}$ described that eosinophilia was present in $73 \%$ of cases of covert toxocariasis, $9 \%$ of incomplete VLM syndrome, and $81 \%$ of suspected cases of OLM. ${ }^{76}$ Theoretically, the absence of eosinophilia occurs in milder or older infections. Eosinophilia of 400 cells $/ \mathrm{mm}^{3}$ is more common in asymptomatic cases, covert toxocariasis, and incomplete VLM syndrome, while eosinophilia above 3,000/ $\mathrm{mm}^{3}$ is typical of classical VLM. ${ }^{67}$

Some authors found no association between the occurrence of eosinophilia and seropositivity for Toxocara infection. 17,19,28,35,119 Many cases reported in the literature of patients with positive serology and symptoms consistent with toxocariasis showed no eosinophilia. $26,69,83,86,94,112,120$ In the literature, there are several cases of toxocariasis with eosinophilia. 1,2,22,25,28,53,59,67,77,121,122 Glickman et al. 97 observed that patients with high IgE and eosinophils in peripheral blood above 400 cells $/ \mathrm{mm}^{3}$ had an $82 \%$ probability of developing toxocariasis. Some authors also demonstrated these associations, ${ }^{23,110,123}$ which suggests that the allergic nature of the infection with $T$. canis. These studies used different cutoff points for eosinophilia, regardless of patients' age, and found associations between eosinophil count above 400,16 1,000,32,58 2,00021 and $3,000^{55}$ cells $/ \mathrm{mm}^{3}$ and positive serology for $T$. canis. It is possible that during the acute phase, eosinophils migrate from the bone marrow to inflamed tissues through peripheral blood flow. When the inflammation becomes chronic, there is a reduction of the chemotactic stimulus and reduction of eosinophil migration. 69

Immunoglobulin $A$, total $G$ and $M$ showed no association with positive serology for $T$. canis according to Figueiredo et al. ${ }^{16}$ On the other hand, Glickman et al. ${ }^{32}$ showed that increased IgG was associated with seropositivity for toxocariasis.

High serum total IgE was associated with positive serology for $T$. canis in adults ${ }^{35}$ and children 16,110 in other studies. In addition to these associations, the presence of hyper-IgE in patients seropositive for Toxocara was reported in several studies. $7,23,77,78,100,115,117$

Some cases of VLM showed significant increase in the titers of anti-A and anti-B isohemagglutinin. ${ }^{28,124}$ Glickman et al. ${ }^{32}$ suggested that anti-A isohemagglutinin titer above 400 can be an important criterion for a presumptive diagnosis of VLM.

The presence of other parasites in children, detected by fecal parasite test, with the possibility of interference in 
the result of serology for $T$. canis was not associated with the seropositivity. ${ }^{16,55}$

It is necessary to demonstrate the presence of worms in the tissue to establish the diagnosis of VLM. ${ }^{125}$ However, this approach has serious limitations because it is difficult to find intact larvae in the eosinophilic granuloma. If the number of larvae is small, it will require hundreds of sections to find the parasite. ${ }^{22}$

Biopsy is the only accepted method to confirm the presence of worms or larvae in the tissues. Because this procedure has an inherent risk, researchers have considered developing an immunological test for the diagnosis of toxocariasis. 126

TES were used for the immunodiagnosis of toxocariasis since 1979 by De Savigny et al. ${ }^{126}$ and later by Lescano et al. ${ }^{127}$ and Ajay et al. ${ }^{128}$ De Savigny et al. ${ }^{126}$ reported that ELISA using antigens TES is a sensitive and specific method for diagnosis of larva migrans for $T$. canis. The sensitivity of the ELISA is over $90 \%{ }^{120}$ and its specificity is from 90 to $95 \% .{ }^{126,129}$ The secretory antigens of the parasite are better indicators of recent or active infection. ${ }^{126}$ The use of this antigen does not require pre-absorption of serum containing embryonated eggs of antigen of Ascaris egg ${ }^{130}$ and there is no cross reaction between this antigen and the serum of individuals infected with Ascaris lumbricoides, Ancylostoma duodenale, Escherichia coli or Giardia lamblia. ${ }^{131}$

In some clinical situations, a lower cutoff point would make the test more efficient to rule out the disease. The low sensitivity of serological tests for OLM is probably related to the low larval burden or the long period between initial infection and the serodiagnostic test. The mean period between the onset of the disease and the serodiagnostic test positivity was less than 6 months in cases of VLM, but about 2 years in cases of OLM. ${ }^{73}$ In human populations, there is a low but variable number of positive ELISA titers between the individuals tested, who apparently show the prevalence of asymptomatic toxocariasis. ${ }^{73}$

Bach-Rizzatti showed that ELISA titers above 640 are related to possible cases of human toxocariasis, suggesting recent infection, 132 being used in Brazilian studies. $28,31,55$ Other cutoff points of these titers above $400,40500^{104,114}$ and $800^{122}$ were also considered positive. Because of the use of different cutoff points in different studies, the interpretation of seroprevalence data becomes very difficult. ${ }^{33}$ A study in mice showed that, 60 days after infection, the chronic phase of VLM is already established. ${ }^{133}$

Since 1992, authors have reported that ultrasound is a tool easily used to detect hypoechoic hepatic granuloma when toxocariasis is in the differential diagnosis, ${ }^{78}$ being a less invasive method with a better cost-benefit ratio for detecting and tracking the changes in toxocariasis. ${ }^{50}$ In 1994, Almeida et al. ${ }^{79}$ showed that abdominal computed tomography poorly revealed hepatic lesions previously demonstrated by abdominal ultrasonography. ${ }^{79}$
In 1979, Glickman et al. ${ }^{32}$ suggested criteria for the diagnosis of toxocariasis based on a case-control study involving 50 children. The criteria included: leukocyte count above $10,000 / \mathrm{mm}^{3}$, eosinophilia above $10 \%$ of leukocytes, anti-A isohemagglutinin titer above 400 and anti-B isohemagglutinin titer above 200, high IgG and IgM, and hepatomegaly. The cases had five or six criteria, and controls under three of these criteria. However, the variables included in the final regression model were IgG and anti-A isohemagglutinin, which were considered important in the presumptive diagnosis of toxocariasis. ${ }^{32}$

In 2001, Pawlowski67 described five markers of symptomatic toxocariasis:

1) patient's characteristics and history;

2) clinical signs and symptoms;

3) positive serology;

4) eosinophilia;

5) increased levels of IgE.

\section{Evolution and prognosis}

Although most patients with toxocariasis have benign prognosis, the larvae can remain alive in the human body for 2 years or more. ${ }^{15} \mathrm{And}$ it is also unclear whether the reduction in eosinophilia and hepatomegaly indicates the interruption of the infectivity with $T$. canis larva. ${ }^{57}$ Whether the larva can persist for long periods also in humans is unkown. ${ }^{57}$ The death of the larvae may also be harmful, possibly because of the substances that are released, which either have a direct irritant effect or stimulate hypersensitivity. ${ }^{57}$

VLM compromises many systems, and its clinical factors, including leukemoid reaction and hypereosinophilia, can mimic many diseases. ${ }^{106,134}$ Delay to diagnose and to initiate specific treatment of systemic toxocariasis can result in damage of the lung, liver and central nervous system associated with significant morbidity and even mortality. ${ }^{106,134,135}$ High eosinophilia is also a complicating factor in systemic toxocariasis as the protein of eosinophilic granuloma may be involved in the tissue damage associated with the disease. ${ }^{136}$

\section{Therapy}

The decision to treat human infection with Toxocara can be difficult. Toxocariasis is most often subclinical and selflimited, but treatment is needed for symptomatic patients. ${ }^{137}$ Human toxocariasis is a chronic infection that can last for many years, and if at some point larval migration occurs, reactivation can occur in the eyes or brain. Therefore, questioning the need for treatment based on the fact that it is a self-limited disease is not a strong argument. 67

There are two rationales for specific treatment of toxocariasis: 1) clinical presentation of each patient; 2) 
attempt to reduce the potential number of larvae migrating to the brain and eyes (Table 1). ${ }^{67}$

Specific treatment is indicated for patients with classic VLM and some cases of incomplete VLM or covert toxocariasis. Because of possible adverse effects, there is no rule for specific treatment of symptomatic ocular and neurological toxocariasis, and each particular patient should be evaluated separately. 67

Among the drugs potentially effective in toxocariasis, only benzimidazoles (albendazole, mebendazole and thiabendazole) and diethylcarbamazine have been tested in controlled studies. ${ }^{137,138}$

Since 1994, several studies used albendazole at a dose of $10 \mathrm{mg} / \mathrm{kg} / \mathrm{day}$, with course ranging from $5,10,15$, and 21 days. $27,50,67,80,102,139,140$

Other authors have used both diethylcarbamazine and thiabendazole and repeated the cycle in some cases. ${ }^{77}$ Some of these authors reported regression of hepatic lesions after 16 months of use of diethylcarbamazine. ${ }^{50,100}$ In some studies, thiabendazole was used at a dose of $25 \mathrm{mg} / \mathrm{kg} /$ day from 3 to 5,7 or 10 days. ${ }^{79,102}$ Other studies used both albendazole for 15 days and thiabendazole $(25 \mathrm{mg} / \mathrm{kg} / \mathrm{day}$ every 8 hours) in two periods of 7 days. 58

Another drug described for the treatment of toxocariasis is ivermectin, ${ }^{141}$ but it did not show response to treatment in relation to eosinophil count. ${ }^{142}$

It is difficult to evaluate the efficacy of the treatment because of the clinical aspects of the disease due to an unspecific symptomatology. ${ }^{7}$ Some markers related to the intensity of infection and active disease process, such as eosinophilia and positive serology for $T$. canis, can help in that decision 7,67 Lopez et al. ${ }^{21}$ demonstrated that IgG titers for Toxocara (ELISA) were not useful for monitoring patients because they remained high for 18 months. Bass et al., ${ }^{94}$ in a study of asymptomatic children, showed no significant reduction in eosinophils 1 year after treatment with thiabendazole, unlike what occurred in relation to ELISA titers for $T$. canis. Souza showed normalization of the levels of IgG ELISA for Toxocara 360 days after treatment with thiabendazole, but there was no statistical difference; however, in relation to the absolute count of leukocytes and eosinophils, there was a statistically significant reduction. ${ }^{31}$ Magnaval ${ }^{143}$ and Obwaller et al. ${ }^{144}$ showed that the intensity of eosinophilia is a better marker than the level of IgE antibodies for treatment evaluation.

\section{Prevention}

The prevention of human toxocariasis can be made as follows. ${ }^{145}$

1) Regular worming of dogs: as the larva passes into breast milk for at least 38 days after the pups are born, four cycles of treatment of pups of 2, 4, 6 and 8 weeks of age should avoid the appearance of transplacental infections or by means of breastfeeding. ${ }^{146}$ The recommendation of worming for older animals is 1-2 times per year. ${ }^{147}$

2) To prevent contamination of soil with feces of dogs in areas immediately adjacent to homes and recreational areas for children. ${ }^{145}$

3) Regular hand washing after contact with soil and before eating and control of geophagy. ${ }^{145}$

4) Reduction of the canine population: the World Health Organization (WHO) recommends that the canine population in each location should correspond to at most $10 \%$ of the human population. ${ }^{148}$

\section{Conclusion}

The epidemiology related to the infection, its risk factors, the most common signs and symptoms and the immunodiagnostic test (IgG ELISA anti-Toxocara canis), which can be used in the diagnosis of human toxocariasis, thus avoiding biopsy, have been described in case reports and observational studies.

Contact with infected dog, especially pups, is a risk factor for infection, which is a reason for concern in term of public health because the presence of dogs in urban areas is becoming increasingly frequent. 149,150

Among the drugs most often used in the treatment of toxocariasis are albendazole or thiabendazole, however, it is necessary to better define the optimal dose and duration of treatment and therapeutic response.

Advances in the development of serological methodology and controlled studies that can define the acute and chronic stages of the disease are needed for the follow-up of patients and control of the infection cure.

\section{References}

1. Beaver PC, Snyder CH, Carrera GM, Dent JH, Lafferty JW. Chronic eosinophilia due to visceral larva migrans: report of three cases. Pediatrics. 1952;9:7-19.

2. Beaver PC. The nature of visceral larva migrans. J Parasitol. 1969;55:3-12.

3. Despommier D. Toxocariasis: clinical aspects, epidemiology, medical ecology, and molecular aspects. Clin Microbiol Rev. 2003;16:265-72.

4. Abe-Jacob CM, Oselka GW. Toxocaríase na infância. Pediatria. 1991;13:48-55.

5. Glickman LT, Schantz PM. Epidemiology and pathogenesis of zoonotic toxocariasis. Epidemiol Rev. 1981;3:230-50.

6. Araujo P. Observações pertinentes à primeiras ecdises de larvas de Ascaris lumbricoides, Ascaris suum e Toxocara canis. Rev Inst Med Trop São Paulo. 1972;14:83-90.

7. Guillaume G, Carlier Y, Losson B, Sternon J. L'hyper-éosinophilie chronique asymptomatique à propos d'un cas de toxocarose professionnelle. Rev Med Brux. 1991;12:209-214.

8. Silva JP. Contaminação de praças do município do Rio de Janeiro por ovos de helmintos. Atas Soc Biol Rio de Janeiro. 1984;24:1-2.

9. Santarém VA, Sartor IF, Bergamo FM. Contaminação por ovos de Toxocara spp. de praças públicas de Botucatu, São Paulo, Brasil. Rev Soc Bras Med Trop. 1998;31:529-32. 
10. Capuano DM, Rocha Gde D. Environmental contamination by Toxocara sp. eggs in Ribeirão Preto, São Paulo State, Brazil. Rev Inst Med Trop São Paulo. 2005;47:223-6.

11. Costa-Cruz JM, Nunes RS, Buso AG. Presença de ovos de Toxocara spp em praças públicas as cidade de Uberlândia, Minas Gerais, Brasil. Rev Inst Med Trop São Paulo. 1994;36:39-42.

12. Alcântara N, Bavia E, Silvão RM, Carvalho E. Environmental contamination by Toxocara spp. eggs in public areas of Salvador, Bahia State, Brazil. Rev Soc Bras Med Trop. 1989;22:187-90.

13. Muradian V, Gennari SM, Glickman LT, Pinheiro SR. Epidemiological aspects of Visceral Larva Migrans in children living at São Remo Community, São Paulo (SP), Brazil. Vet Parasitol. 2005; 134:93-7.

14. Coelho LM, Dini CY, Milman MH, Oliveira SM. Toxocara spp. eggs in public squares of Sorocaba, São Paulo State, Brazil. Rev Inst Med Trop São Paulo. 2001;43:189-91.

15. Bourke GM, Yeates FM. Blindness due to household pets. Med J Aust. $1961 ; 48: 12-4$

16. Figueiredo SD, Taddei JA, Menezes JJ, Novo NF, Silva EO, Cristóvão $\mathrm{HL}$, et al. Estudo clínico-epidemiológico da toxocaríase em população infantil. J Pediatr (Rio J). 2005;81:126-32.

17. Anaruma Filho F, Chieffi PP, Correa CR, Camargo ED, Silveira EP, Aranha JJ, et al. Human toxocariasis: a seroepidemiological survey in the municipality of Campinas (SP), Brazil. Rev Inst Med Trop São Paulo. 2002;44:303-7.

18. Mizgajska $\mathrm{H}$. The role of some environmental factors in the contamination of soil with Toxocara spp. and other geohelminth eggs. Parasit Int. 1997;46:67-72.

19. Glickman LT, Chaudry IU, Costantino J, Clack FB, Cypess RH, Winslow L. Pica patterns, Toxocariasis, and elevated blood lead in children. Am J Trop Med Hyg. 1981;30:77-80.

20. Coelho LM, Silva MV, Dini CY, Giacon Neto AA, Novo NF, Silveira EP. Human toxocariasis: a seroepidemiological survey in schoolchildren of Sorocaba, Brazil. Mem Inst Oswaldo Cruz. 2004;99:533-7.

21. Lopez Mde L, Martin G, Chamorro Mdel C, Mario Alonso J. Toxocariasis in children from a subtropical region. Medicina ( $B$ Aires). 2005;65:226-30.

22. Zinkham WH. Visceral larva migrans. A review and reassessment indicating two forms of clinical expression: visceral and ocular. Am J Dis Child. 1978;132:627-33.

23. Marmor M, Glickman L, Shofer F, Faich LA, Rosenberg C, Cornblatt $B$, et al. Toxocara canis infection of children: epidemiologic and neuropsychologic findings. Am J Public Health. 1987;77:554-9.

24. Ellis GS Jr, Pakalnis VA, Worley G, Green JA, Frothingham TE, Sturner RA, et al. Toxocara canis infestation. Clinical and epidemiological associations with seropositivity in kindergarten children. Ophthalmology. 1986;93:1032-7.

25. Snyder $\mathrm{CH}$. Visceral larva migrans Ten years'experience. Pediatrics. $1961 ; 28: 85-91$

26. Sabrosa NA, de Souza EC. Nematode infections of the eye: toxocariasis an diffuse unilateral subacute neuroretinitis. Curr Opin Ophthalmol. 2001;12:450-4.

27. Trabelsi S, Belhadj S, Kallel K, Zouiten F, Ben Becheur S, Ben Ayed $\mathrm{N}$, et al. La toxocarose: une pathologie sous-estimée. A propos de 9 cas. Tunis Med. 2004;82:684-9.

28. Abe-Jacob CM. Contribuição para o estudo da toxocaríase na infância: aspectos clínico-laboratoriais de 40 casos [dissertação]. São Paulo: Universidade de São Paulo; 1990.

29. Ajayi OO, Duhlinska DD, Agwale SM, Njoku M. Frequency of human toxocariasis in Jos, Plateau State, Nigeria. Mem Inst Oswaldo Cruz. 2000;95:147-9.

30. Iddawela DR, Kumarasiri PV, Wijesundera MS. A seroepidemiological study of toxocariasis and risk factors for infection in children in Sri Lanka. Southeast Asian J Trop Med Public Health. 2003;34:7-15.

31. Souza FA. Parâmetros clínicos laboratoriais na evolução de 104 crianças portadoras de larva migrans visceral por Toxocara canis [dissertação]. São Paulo: UFESP; 1992.

32. Glickman LT, Schantz PM, Cypess RH. Epidemiological characteristics and clinical findings in patients with serologically proven toxocariasis. Trans R Soc Trop Med Hyg. 1979;73:254-8.

33. Alderete JM, Jacob CM, Pastorino AC, Rubinsky-Elefant G, Castro AP, Fomin $A B$, et al. Prevalence of Toxocara infection in schoolchildren from the Butantã region, São Paulo, Brazil. Mem Inst Oswaldo Cruz. 2003;98:593-7.
34. Schantz PM, Meyer D, Glickman LT. Clinical, serologic, and epidemiologic characteristics of ocular toxocariasis. Am J Trop Med Hyg. 1979;28:24-8.

35. Gonzalez-Quintela A, Gude F, Campos J, Garea MT, Romero PA, Rey J, et al. Toxocara infection seroprevalence and its realtionship with atopic features in a general adult population. Int Arch Allergy Immunol. 2006;139:317-24.

36. Fan CK, Liao CW, Kao TC, Li MH, Du WY, Su KE. Sero-epidemioloy of Toxocara canis infection among aboriginal schoochildren in the mountainous areas of north-eastern Taiwan. Ann Trop Med Parasitol. 2005;99:593-600.

37. Kanafani ZA, Skoury A, Araj GF, El-Khoury M, Sawaya RA, Atweh SF, et al. Seroprevalence of toxocariasis in Lebanon: a pilot study. Parasitology. 2006;132:635-9.

38. Caseiro MM. Síndrome de Larva Migrans Visceral causada por Larvas de Toxocara canis, no município de Santos [dissertação]. São Paulo: Faculdade de Medicina, Universidade de São Paulo; 1996.

39. Kayes SG. Human toxocariasis and the visceral larva migrans syndrome: correlative immunopathology. Chem Immunol. 1997;66:99-124.

40. Lynch NR, Wilkes LK, Hodge AN, Turner KJ. Specificity of Toxocara ELISA in tropical populations. Parasite Immunol. $1988 ; 10: 323-37$

41. Overgaauw PA. Aspects of Toxocara epidemiology: human toxocarosis. Crit Rev Microbiol. 1997;23:215-31.

42. Chieffi PP, Ueda M, Camargo ED, de Souza AM, Guedes ML, Gerbi LJ, et al. Visceral larva migrans: a seroepidemiological survey in five municipalities of Sao Paulo state, Brazil. Rev Inst Med Trop Sao Paulo. 1990;32:204-10.

43. Genchi C, Di Sacco B, Gatti S, Sangalli G, Scaglia M. Epidemiology of human toxocariasis in northern Italy. Parassitologia. $1990 ; 32: 313-9$.

44. Campos Júnior D, Elefant GR, de Melo e Silva EO, Gandolfi L, Abe Jacob CM, Tofeti A, et al. Frequency of seropositivy to Toxocara canis in children of different socioeconomic strata. Rev Soc Bras Med Trop. 2003;36:509-13.

45. Cancrini G, Bartoloni A, Zaffaroni E, Guglielmetti P, Gamboa H, Nicoletti A, et al. Seroprevalence of Toxocara canis-IgG antibodies in two rural Bolivian communities. Parassitologia. 1998;40:473-5.

46. García-Pedrique $M E$, Días-Suárez $O$, Esteves J, Cheng-Ng R, Araujo-Fernández M, Castellano J, et al. Prevalencia de infección por Toxocara em pré-escolares de una comunidad educativa de El Moján, Estado Zulia, Venezuela. Resultados preliminares. Invest Clin. 2004;45:347-54.

47. Malla N, Aggarwal AK, Mahajan RC. A serological study of human toxocariasis in north India. Natl Med J India. 2002;15:145-7.

48. Huerga Aramburu H, López-Vélez R. Estudio comparativo de la patologia infecciosa em niños inmigrantes de distintas procedências. An Pediatr (Barc). 2004;60:16-21.

49. Taranto NJ, Passamonte L, Marinconz R, de Marzi MC, Cajal SP, Malchiodi EL. Parasitosis zoonotic transmitidas por perros em el Chaco salteño. Medicina (B Aires). 2000;60:217-20.

50. Gónzalez MT, Ibañez O, Balcarce N, Nanfito G, KoZubsky L, Radman $\mathrm{N}$, et al. Toxocariasis with liver involvement. Acta Gastroenterol Latinoam. 2000;30:187-90.

51. Paolillo F, Migliori C, Fornari M, Belloni C. Toxocariasi: descrizione di un caso. Pediatr Med Chir. 1997;19:141-2.

52. Amir J, Harel L, Eidlitz-Markus T, Varzano I. Lymphedema as a presenting sign of Toxocariasis. Infection. 1995;23:389-90.

53. de Corral VR, Lozano-García J, Ramos-Corona LE. An unsual case of systemic toxocariasis. Bol Med Hosp Infant Mex. $1990 ; 47: 841-4$

54. Kagialis-Girard S, Mialou V, Ffrench M, Dupuis-Girod S, Pages MP, Bertrand Y. Thrombocytosis and toxocariasis: report of two pediatric cases. Pediatr Blood Cancer. 2005;44:190-2.

55. Aguiar-Santos AM, Andrade LD, Medeiros Z, Chieffi PP, Lescano SZ, Perez EP. Human toxocariasis: frequency of anti-Toxocara antibodies in children and adolescents from an outpatient clinic for lymphatic filariasis in Recife, Northeast Brazil. Rev Inst Med Trop Sao Paulo. 2004;46:81-5.

56. Buyukbaba O, Ozkan E, Buget E. Toxocara canis infection ans ivestigation of its seroprevalence in children by ELISA. Turk J Infect. 1996;10:7-11.

57. Mok $\mathrm{CH}$. Visceral larva migrans. A discussion based on review of the literature. Clin Pediatr (Phila). 1968;7:565-73. 
58. Altcheh J, Nallar M, Conca M, Biancardi M, Freilij H. Toxocariasis: clinical and laboratory features in 54 patients. An Pediatr (Barc). 2003;58:425-31.

59. Chang S, Lim JH, Choi D, Park CK, Kwon NH, Cho SY, et al. Hepatic visceral larva migrans of Toxocara canis: CT and sonographic findings. AJR Am J Roentgenol. 2006;187:W622-9.

60. Maestrini AA. Aspectos clínicos e epidemiológicos da toxocaríase na população escolar do município de Rio Acima, Região Metropolitana de Belo Horizonte, Minas Gerais [Tese]. Belo Horizonte: Faculdade de Medicina, Universidade Federal de Minas Gerais; 1995.

61. De Andrade Lima Coelho R, De Carvalho LB Jr, Perez EP, Araki K, Takeuchi T, Ito A, et al. Prevalence of toxocariasis in northeastern Brazil based on serology using recombinant Toxocara canis antigen. Am J Trop Med Hyg. 2005;72:103-7.

62. Anaruma Filho F, Chieffi PP, Correa CR, Camargo ED, Silveira EP, Aranha JJ, et al. Human Toxocariasis: a seroepidemiological survey in the municipality of Campinas (SP), Brazil. Rev Inst Med Trop Sao Paulo. 2002;44:303-7.

63. Anaruma Filho F, Chieffi PP, Correa CR, Camargo ED, da Silveira EP, Aranha JJ. Human toxocariasis: incidence among residents in the outskirts of Campinas, State of São Paulo, Brazil. Rev Inst Med Trop Sao Paulo. 2003,45:293-4.

64. Matos M de F, Militão DN, Brum MA, Omais M, Quilião ME, Dorval $M E$, et al. Presence of anti-Toxocara antibodies in children selected at Hospital Universitário, Campo Grande, MS, Brazil. Rev Inst Med Trop Sao Paulo. 1997;39:49-50.

65. Virgínia P, Nagakura K, Ferreira O, Tateno S. Serologic evidence of toxocariasis in northeast Brazil. Jpn J Med Sci Biol. 1991;44:1-6.

66. Moreira-Silva FS, Leão ME, Mendonça HF, Pereira FE. Prevalence of anti-Toxocara antibodies in a random sample of inpatients at a children's hospital in Vitória, Espírito Santo, Brazil. Rev Inst Med Trop Sao Paulo. 1998;40:259-61.

67. Pawlowski Z. Toxocariasis in humans: clinical expression and treatment dilemma. J Helminthol. 2001;75:299-305.

68. Loez Mde L, Martin G, Chamorro Mdel C, Mario Alonso J. Toxocariossis en ninõs de una region subtropical. Medicina ( $B$ Aires). 2005;65:226-230.

69. Taylor MR, Keane CT, O'Connor P, Mulvihill E, Holland C. The expanded spectrum of toxocaral disease. Lancet. 1988; 1:692-5.

70. Nathwani D, Laing RB, Currie PF. Covert toxocariasis - a cause of recurrent abdominal pain in childhood. $\mathrm{Br} \mathrm{J}$ Clin Pract. 1992;46:271.

71. Rasmussen LN, Dirdal M, Birkebaek NH. "Covert toxocariasis" in a child treated with low-dose diethylcarbamazine. Acta Paediatr. 1993;82:116-8.

72. Magnaval JF, Dorchies $\mathrm{P}$, Morassin $\mathrm{B}$. Actualités de la toxocarose humaine. Pyrexie. 2000;4:111-5.

73. Schantz PM. Toxocara larva migrans now. Am J Trop Med Hyg. 1989;41:21-34.

74. Kendell KR, Day JD, Hruban RH, Olson JL, Rosemblum WD, Kasper $E K$, et al. Intimate association of eosinophils to collagen bundles in eosinophilic myocarditis ans ranitine-induced hypersensitivity myocarditis. Arch Pathol Lab Med. 1995;119:1154-60.

75. Hokibara S, Takamoto M, Isobe M, Sugane K. Effects of monoclonal antibodies to adhesion molecules on eosinophilic myocarditis in Toxocara canis-infected $\mathrm{CBA} / \mathrm{J}$ mice. Clin Exp Immunol. 1998;114:236-44.

76. Luzna-Lyskov A. Toxocarosis in children living in a highly contaminated area. An epidemiological and clinical study. Acta Parasitol. 2000;45:40-2.

77. Baldisserotto M, Conchin CF, Soares Mda G, Araujo MA, Kramer B. Ultrasound findings in children with toxocariasis: report on 18 cases. Pediatr Radiol. 1999;29:316-9.

78. Ishibashi H, Shimamura R, Hirata Y, Kudo J, Onizuka H. Hepatic granuloma in toxocaral infection:role of ultrasonography in hypereosinophilia. J Clin Ultrasound. 1992;20:204-10.

79. Almeida MT, Ribeiro RC, Kauffman WM, Maluf Júnior PT, Brito JL, Cristofani LM, et al. Toxocariasis simulating hepatic recurrence in a patient with Wilms' tumor. Med Pediatr Oncol. $1994 ; 22: 211-5$
80. Dogan S, Beyazit Y, Altintas ND, Aksu S, Oz SG, Iskit AT, et al. Systemic toxocariasis presenting with leukemoid reaction and hypereosinophilia. Am J Hematol. 2005;79:171.

81. Herry I, Philippe B, Hennequin C, Danel C, Lejeunne C, Meyer G. Acute life-threatening toxocaral tamponade. Chest. 1997; 112:1692-3.

82. Good B, Holland CV, Taylor MR, Larragy J, Moriarty P, O'Regan M. Ocular toxocariasis in schoolchildren. Clin Infect Dis. 2004;39:173-8.

83. Oréfice F, Boratto LM, Silva HF. Presumível toxocaríase ocular: revisão de 30 casos (1978-1989); relato de dois casos atípicos. Rev Bras Oftalmol. 1991;50:31-7.

84. Cochereau I. Infections ocularires. Encycl Méd Chir (Elsevier, Paris). Maladies infectieuses; 8-003-L-10; 2000.

85. Stewart JM, Cubillan LD, Cunningham ET Jr. Prevalence, clinical feature, and causes of vison loss among patients with ocular toxocariasis. Retina. 2005;25:1005-13.

86. Magnaval JF, Glickman LT, Dorchies P, Morassin B. Highlights of human toxocariasis. Korean J Parasitol. 2001;39:1-11.

87. Logar J, Soba B, Kraut A, Stirn-Kranjc B. Seroprevalence of Toxocara antibodies amongzpatients suspected of ocular toxocariasis in Slovenia. Korean J Parasitol. 2004;42:137-40.

88. Nicoletti A, Bartoloni A, Reggio A, Bartalesi F, Roselli M, Sofia V, et al. Epilepsy, cysticercosis, and toxocariasis: a population-based case-control study in rural Bolivia. Neurology. 2002;58:1256-61.

89. Bächli H, Minet JC, Gratzl O. Cerebral toxocariasis: a possible cause of epileptic seizure in children. Childs Nerv Syst. 2004;20:468-72.

90. Buijs J, Egbers MW, Lokhorst WH, Savelkoul HF, Nijkamp FP. Toxocara-induced eosinophilic inflammation. Airway function and effect of anti-IL-5. Am J Respir Crit Care Med. $1995 ; 151: 873-8$

91. Feldman GJ, Parker HW. Visceral larva migrans associated with the hypereosinophilic syndrome and the onset of sever asthma. Ann Intern Med. 1992;116:838-40.

92. Wolfrom E, Chene G, Boisseau H, Beylot C, Geniaux M, Taïeb A. Chronic urticaria and Toxocara canis. Lancet. 1995;345:196.

93. Le Luyer B, Menager V, Andebert C, Le Ropux P, Briguet MT, Boulloche J. Inflamatory joint disease as a manifestation of Toxocara canis larva migrans. Ann Pediatr (Paris). $1990 ; 37: 445-8$

94. Bass JL, Mehta KA, Glickman LT, Blocker R, Eppes BM. Asymptomatic toxocariasis in children. A prospective study and treatment trial. Clin Pediatr (Phila). 1987;26:441-6.

95. Taylor MR, Keane CT, O'Connor P, Girdwood RW, Smith H. Clinical features of covert toxocariasis. Scand J Infect Dis. 1987;19:693-6

96. Hassan MM, Farghaly AM, Gaber NS, Nageeb HF, Hegab MH, Galal N. Parasitic causes of hepatomegaly in children. J Egypt Soc Parasitol. 1996;26:177-89.

97. Glickman LT, Magnaval JF, Domanski LM, Shofer FS, Lauria SS, Gottstein B, et al. Visceral larva migrans in French adults: a new disease syndrome? Am J Epidemiol. 1987;125:1019-34.

98. Jain R, Sawhney S, Bhargava DK, Panda SK, Berry M. Hepatic granulomas due to visceral larva migrans in adults: appearance on US and MRI. Abdom Imaging. 1994;19:253-6.

99. Hirata T, Yamasaki K, Li YG, Majima Y, Tsuji M. Demonstration of hepatic granuloma due to visceral larva migrans by ultrasonography. J Clin Ultrasound. 1990;18:429-33.

100. Clarke HM, Hinde FR, Manns RA. Case report: hepatic ultrasound findings in a case of toxocariasis. Clin Radiol. 1992;46:135-6.

101. Kaplan KJ, Goodman ZD, Ishak KG. Eosinophilic granuloma of the liver: a charcterisitic lesion with reationship to visceral larva migrans. Am J Surg Pathol. 2001;25:1316-21.

102. Azuma K, Yashiro N, Kinoshita T, Yoshigi J, Ihara N. Hepatic involvement of visceral larva migrans due Toxocara canis: a case report-CT and MR findings. Radiat Med. 2002;20:89-92.

103. Pereira FE, Musso C, Castelo JS. Pathology of pyogenic liver abscess in children. Pediatr Dev Pathol. 1999;2:537-43.

104. Moreira-Silva SF, Pereira FE. Intestinal nematodes, Toxocara infection, and pyogenic liver abscess in children: a possible association. J Trop Pediatr. 2000;46:167-72. 
105. Rayes AA, Teixeira D, Serufo JC, Nobre V, Antunes CM, Lambertucci JR. Human toxocariasis and pyogenic liver abscess: a possible association. Am J Gastroenterol. 2001;96:563-6.

106. Jeanfaivre T, Cimon B, Tolstuchow N, de Gentile L, Chabasse D, Tuchais E. Pleural effusion and toxocariasis. Thorax. 1996;51:106-7.

107. Sakai K, Hirasawa $Y$, Hashimoto A. A case of toxocariasis with eosinophil-rich pleural effusion. Nihon Kokyuki Gakkai Zasshi. 2002;40:494-8.

108. Ashwath ML, Robinson DR, Katner HP. A presumptive case of toxocariasis associated with eosinophilic pleural effusion: case report and literature review. Am J Trop Med Hyg. 2004;71:764.

109. Buijs J, Borsboom G, Renting M, Hilgersom WJ, van Wieringen JC, Jansen G, et al. Relationship between allergic manifestations and Toxocara seropositivity: a cross-sectional study among elementary school children. Eur Respir J. 1997;10:1467-75.

110. Buijs J, Egbers MW, Nijkamp FP. Toxocara canis induced airway hyperactivity in mice. Agent Actions Suppl. 1990;31:75-80.

111. Buijs J, Borsboom G, van Gemund JJ, Hazebroek A, van Dongen $\mathrm{PA}$, van Knapen $\mathrm{F}$, et al. Toxocara seroprevalence in 5-year-old elementary schoolchildren: relation with allergic asthma. Am J Epidemiol. 1994;140:839-47.

112. Radman NE, Archelli SM, Fonrouge RD, del V Guardis M, Linzitto OR. Human toxocarosis. Its seroprevalence in the City of La Plata. Mem Inst Oswaldo Cruz. 2000;95:281-5.

113. Rayes AA, Lambertucci JR. Human toxocariasis as a possible cause of eosinophilic arthritis. Rheumatology (Oxford). 2001;40:109-10

114. Rayes AA, Nobre V, Teixeira DM, Serufo JC, Filho GB, Antunes $\mathrm{CM}$, et al. Tropical pyomyositis and human toxocariasis: a clinical and experimental study. Am J Med. 2000;109:422-5.

115. Lambertucci JR, Rayes AA, Serufo JC, Nobre V. Pyogenic abscesses and parasitic diseases. Rev Inst Med Trop Sao Paulo. 2001;43:67-74.

116. Rayes AA, Lambertucci JR. Visceral larva migrans and pyogenic liver abscess. Am J Gastroenterol. 1999;94:1116.

117. Carme B. Larva migrans visceral (toxocarose). Dans: Nozais JP, Datry A, Danis M. Traité de Parasitologie, Paris: Editions Pradel; 1996. p. 495-8.

118. Meeusen EN, Balic A. Do eosinophils have a role in the killing of helminth parasites? Parasitol Today. 2000;16:95-101.

119. Gueglio B, de Gentile L, Nguyen JM, Achard J, Chabasse D, Marjolet M. Epidemiologic approach to human toxocariasis in western France. Parasitol Res. 1994;80:531-6.

120. Jacquier $P$, Gottstein B, Stingelin $Y$, Eckert J. Immunodiagnosis of toxocarosis in humans: evaluation of a new enzyme-linked immunosorbent assay kit. J Clin Microbiol. 1991;29:1831-5.

121. Hotez PJ. Visceral and ocular larva migrans. Semin Neurol. 1993; 13:175-9

122. Portús M, Riera C, Prats G. A serological survey of toxocariasis in patients and healthy donors in Barcelona (Spain). Eur J Epidemiol. 1989,5:224-7.

123. Alonso JM, Bojanich MV, Chamorro M, Gorodner JO. Toxocara seroprevalence in children from a subtropical city in Argentina. Rev Inst Med Trop Sao Paulo. 2000;42:235-7.

124. Huntley CC, Lyerly $A D$, Patterson MV. Isohemagglutinins in parasitic infections. JAMA. 1969;208:1145-8.

125. Jung RC, Pacheco G. Use of a hemagglutination test in visceral larva migrans. Am J Trop Med Hyg. 1960;9:185-91.

126. De Savigny DH, Voller A, Woodruff AW. Toxocariasis: serological diagnosis by enzyme immunoassay. J Clin Pathol. 1979;32:284-8.

127. Lescano SA, Chieffi PP, Peres BA, de Mello EO, Velarde CN, Salinas AA, et al. Soil contamination and human infection by Toxocara sp. in the urban area of Lima, Peru. Mem Inst Oswaldo Cruz. 1998;93:733-4.

128. Ajayi OO, Duhlinska DD, Agwale SM, Njoku M. Frequency of human toxocariasis in Jos, Plateau State, Nigeria. Mem Inst Oswaldo Cruz. 2000;95:147-9.

129. Magnaval JF, Glickman LT, Dorchies P. Toxocarose. Dans: Ripert C. Epidémiologie des maladies parasitaires Tome 2, Cachan: Editions Médicales Internationales; 1998. p. 527-49.
130. De Savigny DH. In vitro maintenance of Toxocara canis larvae and a simple method for the production of Toxocara ES antigen for use in serodiagnostic tests for visceral larva migrans. J Parasitol. 1975;61:781-2.

131. Glickman LT, Grieve RB, Lauria SS, Jones DL. Serodiagnosis of ocular toxocariasis: a comparison of two antigens. J Clin Pathol. $1985 ; 38: 103-7$

132. Bach-Rizzati BC. Desenvolvimento de teste imunoenzimático, ELISA, para o diagnóstico da toxocaríase humana [Tese]. São Paulo, SP: Universidade de São Paulo, Faculdade de Ciências Farmacêuticas; 1984.

133. Schoenardie ER. Diagnóstico imunoenzimático da larva migrans visceral [Dissertação]. Pelotas, RS: Universidade Federal de Pelotas; 2005.

134. Bachmeyer C, Lamarque G, Morariu R, Molina T, Bourée P, Delmer A. Visceral larva migrans mimicking Lymphoma. Chest. 2003;123:1296-7.

135. Arango CA. Visceral larva migrans and the hypereosinophilia syndrome. South Med J. 1998; 91:882-3.

136. Fondati A, Carreras E, Fondevila MD, Ferrer L, Cuchillo CM, Nogues MV, et al. Characterization of bilological activities of feline eosinophil granule proteins. Am J Vet Res. 2004;65:957-63.

137. Caumes E. Treatment of cutaneous larva migrans and Toxocara infection. Fundam Clin Pharmacol. 2003;17:213-6.

138. Sturchler D, Schubarth P, Gualzata M, Gottstein B, Oettli A. Thiabendazole vs, albendazole in treatment of toxocariasis: a clinical trial. Ann J Trop Med Parasitol. 1989;83:473-8.

139. Bathia V, Sarin SK. Hepatic Visceral larva migrans: evolution of the lesion, diagnosis, and role of high-dose albendazole therapy. Am J Gastroenterol. 1994;89:624-7.

140. Barisani-Asenbauer T, Maca SM, Hauff W, Kaminski SL, Domanovits $\mathrm{H}$, Theyer I, et al. Treatment of ocular toxocariasis with albendazole. J Ocul Pharmacol Ther. 2001;17:287-94.

141. Elgart GW, Meinking TL. Ivermectin. Dermatol Clin. 2003;21:277-82.

142. Magnaval JF. Apparent weak efficacy of ivemectin for treatment of human toxocariasis. Antimicrob Agents Chemother. $1998 ; 42: 2770$.

143. Obwaller A, Auer H, Jensen-Jarolim E, Leitner A, Kraft D, Aspöck $\mathrm{H}$. Die diagnostische Bedeutung des Nachweives specifischer IgE-Anti-Koeper bei Toxocara-Infestationen. Mitteilungen der Oesterreichischen Gesellschaft für Tropenmedizin und Parasitol. 1996;18:201-6.

144. Magnaval JF, Fabre R, Mauriéres $P$, Charlet JP, de Larrard B. Evaluation of an immunoenzymatic assay detecting specific anti-Toxocara immunoglobulin $E$ for diagnosis and posttreatment follow-up of human toxocariasis. J Clin Microbiol. 1992;30:2269-74.

145. Benenson AS. Control of communicable diseases manual. American Public Health Association, 16th ed. Washington, DC; 1995.

146. Zimmermann U, Lowenstein MD, Stoye M. Untersuchungen uber die Wanderung und Streuung der Larven von Toxocara canis Werner 1782 (Anisakidae) im definitiven Wirt (Beagle) nach Erst-und Reinfection. Z Veterinar Med. 1985;32:1-28.

147. Maizels RM, Meghji M. Repeated patent infection of adult dogs with Toxocara canis. J Helminthol. 1984;58:327-33.

148. World Health Organization/Zoon. Guidelines for dog population manegement. Geneve, WHO; 1990.

149. Fok E, Rozgonyi F. Epidemiology and public health consequences of human toxocariasis as a frequently occurring urban zoonosis. Orv Hetil. 1999;140:1513-8.

150. Luzna-Lyskov A, Andrzejewska I, Lesicka U, SzewczykKramska B, Luty T, Pawlowski ZS. Clinical interpretation of eosinophilia and ELISA values (OD) in toxocarosis. Acta Parasitol. 2000;45:35-9.

Correspondence:

Elaine Alvarenga de Almeida Carvalho

Rua Rio Grande do Sul, 1118/801 - Santo Agostinho

CEP 30170-111 - Belo Horizonte, MG - Brazil

E-mail: elaineacarvalho@terra.com.br 